\title{
An Evaluation on the Sexual Mutilation in Females of Gylippus Simon, 1879 species (Gylippinae, Gylippidae, Solifugae)
}

\author{
Melek ERDEK ${ }^{*}$ \\ Hakkâri University, Vocational School of Health Services, Department of Medical Services and Techniques, \\ Hakkâri, Turkey \\ (ORCID: 0000-0003-1060-4265)
}

\begin{abstract}
The genital sternite is differentiated from other opisthosomal sternites in female gylippids and used for identification as a distinctive characteristic. In the present study, twenty-four female specimens belong to Gylippus Simon genus were examined. The female specimens collected from different localities of Turkey. Gylippus (Gylippus) erseni Koç\&Erdek, 2019, Gylippus (Gylippus) syriacus Simon, 1872, Gylippus (Hemigylippus) bayrami Erdek, 2015, Gylippus (Paragylippus) monoceros Werner, 1905 and Gylippus sp. belong, including five different species It has been noted that, the male exhibits aggressive and compulsive behaviours after approaching the female during the mating period. The deformations and cuticular injuries on the genital segment, caused difficulties in species identification, are derived from the coercive copulation behaviour during the mating and premating process
\end{abstract}

Key words: Solifuge, Gylippus, Solifugae, deformation, coercive copulation.

\section{Gylippus Simon, 1879 Türlerinin Dişi Bireylerinde Eşeysel Deformasyon Üzerine Bir Değerlendirme (Gylippinae, Gylippidae, Solifugae)}

\section{$\ddot{O} \mathbf{z}$}

Genital sternit dişi gylippidlerde diğer abdominal sternitlerden farklılaşmış olup ayırt edici karakter olarak teşhiste kullanılır. Bu çalışma kapsamında, Gylippus Simon cinsine ait 24 dişi bireyin genital segmentleri incelenmiştir. Türkiye'nin farklı bölgelerinden toplanan dişi örnekler, Gylippus (Gylippus) erseni Koç\&Erdek, 2019, Gylippus (Gylippus) syriacus Simon, 1872, Gylippus (Hemigylippus) bayrami Erdek, 2015, Gylippus (Paragylippus) monoceros Werner, 1905 ve Gylippus sp. olmak üzere 5 farklı türe aittir. Çiftleşme döneminde erkeğin dişiye yaklaşması sonrasında saldırgan ve zorlayıcı davranışlar sergilediği kaydedilmiştir. Zaman zaman tür teşhisinde zorlanmalara neden olan genital segmentteki bu deformasyonlar ve kütikular yaralar çiftleşme sırasında ve çiftleşme öncesindeki zorlayıcı davranışından ileri gelmektedir.

Anahtar kelimeler: Böğü, Gylippus, Solifugae, deformasyon, zorlayıcı çiftleşme.

\section{Introduction}

Solifuges are still not well-known arachnid order with 1123 species belong to 138 genera and 12 families $[1-5,8,9]$. Opisthosoma typically consists of ten segments and the $1^{\text {st }}$ opisthosomal segment is known as the genital segment. The genital opercula have generally different shapes in different families' species. In gylippids genital segment consists of two parts; genital opening and genital lobes. The female genital organs of adult solifuges are divided into three different parts; genital chamber, oviducts, and ovary $[7,13]$.

Muma [10] summarized the mating behaviour in Eremobates species in three phases as attack phase, contact phase, and release phase. He emphasized that male grasping female genital segment with chelicerae especially chewing vigorously the female genital opercular area. Peretti and Willemart [12] illustrated the presence of sexual coercion during mating of Oltacola chacoensis Roewer, 1934 
(Ammotrechidae). They pointed to cuticular injuries on abdominal segments and genital opening in females during mating. Hrušková-Martišová et al. [5] studied the behaviour of coercive copulation in Galeodes caspius subfuscus Birula, 1937 (Galeodidae) and Gluvia dorsalis (Latreille, 1817) (Daesiidae). They also indicated injuries on the cuticles of the genital organ and $4^{\text {th }}$ legs in females and broken tips on male chelicerae during copulation.

The present study examines the genital mutilation and cuticular damages in some female gylippids. The injuries and female genital deformations caused by the pedipalpal setae and chelicerae of males during capturing and forcing pre-mating and mating.

\section{Material and Methods}

Specimens were collected with hand-sampling method during daytime and pitfall traps techniques from different localities of Turkey from March to September in 2007-2019:

*Gylippus (Gylippus) erseni

-(2웅, Figs.2h-i). Karaman Province, Karadağ Mountain, 9 km west of Dinek Village, 37²3'20'N, 330'1'ㅌ, 2100m a.s.1., 01.09.2012, leg. E.A. Yağmur.

*Gylippus (Gylippus) syriacus

-(1우, Fig.1a) Diyarbakır Province, Ergani District, 1km northwest of Salihli Village, 38¹3'38’N, 39³1'05'E, 12.04.2008, leg. E.A. Yağmur.

-(1ㅇ, Fig.1b) Diyarbakır Province, Çermik District, 3807’11’N, 3907’43”'E, 12.04.2008. leg. E.A. Yağmur.

-(2우, Fig.1c-d) Diyarbakır Province, $3 \mathrm{~km}$ south of Silvan District, Köçek Mountain, 38¹1'21'N, 4100'30’'E, 15.04.2008, leg. E.A. Yağmur.

-(1ㅇ, Fig.1j) Gaziantep Province, Oğuzeli District, 2km south of Çaybaşı Village, 3659'58”N, 37³0'48’E, 729m a.s.1, 17.04.2009, leg. E.A. Yağmur.

-(1ㅇ, Fig.1k) Mardin Province, Yeşilli District, 37¹9’57.0”N, 4048’58.8”E, 751m a.s.1., 15.03.2013, leg. M. Erdek.

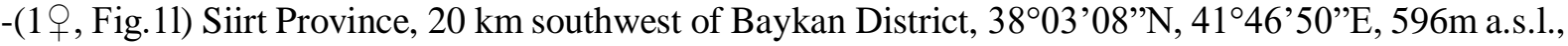
18.0.2009, leg. E.A. Yağmur.

-(6웅, Fig.2a-f) Şanlıurfa Province, Birecik District, Arat Mountain, 37¹9'57.0”N, 4048'58.8”E, 663m a.s.1., 15.03.2013, leg. M. Erdek.

-(1 , Fig. $2 \mathrm{~g})$ Batman Province, $5 \mathrm{~km}$ north of Gercüş District, 17.05.2009, leg. E.A. Yağmur.

*Gylippus (Paragylippus) monoceros

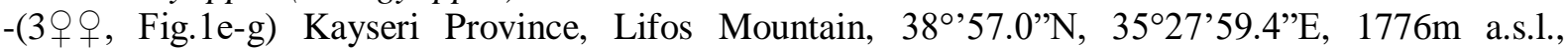
24.05.2013, leg. M. Erdek.

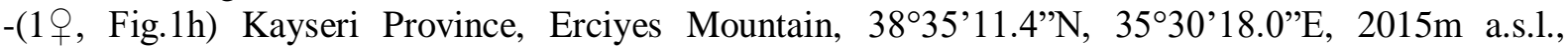
20.05.2011, leg. M. Erdek.

*Gylippus (Hemigylippus) bayrami

--(1, Fig.1i) Erzincan Province, Çağlayan District, Kalecik Village, 39³4'11’'N, 35²9’50”E, 1776m a.s.1., 18.05.2011, leg. İ. Özgen\&S. Anlaş.

* Gylippus sp. were collected from Adana province (2j-1).

The pictures of female genital organs were illustrated using a Leica DFC295 camera attached to the Leica DFC295 stereo microscope. Birula (1913) and Roewer (1933) were used for descriptions of the species $[1,14]$.

\section{Results}

The genital sternites in different gylippid species as in Figs. 1-2 and prominently differentiated from other abdominal sternites. The genital lobes are interspecifically variable and they are not fully opened or fully unified in immature females. These lobes are not completely curling and shaping (Figs. 11, 2b).

The cuticular damages during the attack phase of mating could be evaluated under 4 headings: genital segment damages, genital lobes damages, genital opening damages, $4^{\text {th }}$ leg segments, and abdominal damages.

Genital segment damages: These damages mostly consist of on the proximal side of the genital segment, close to the posterior abdominal sternite (Figs. 1a, 2c, f, g). These damages are in the form of 
darkening in the color and hardening in the cuticle. And also there are folding and prominent deformities on the genital segment surface (Figs. 1d, j-k, 2e, g, j-1).

Genital lobes damages: In many examined specimens, right and left genital lobes do not seem equal and symmetrical (especially Figs. 1a, c-d, 2k-1). The width of notches at the posterior side of these lobes are also not equal in the same species (Figs. 1d, f). There are some cuticular darkening due to tissue damages on lobes and the notch edges (Figs. 1a, f, 2c, h-i).

Genital opening damages: The cuticular tissue in the genital opening prominently bulges outwardly(Figs. 1f, j-k, 2a, e, j-1). There are also some scars on the genital opening (Figs. 1a, f-g, j, 2d). The $4^{\text {th }}$ leg segments and opisthosomal damages. The scars are observed on the $3^{\text {rd }}$ opisthosomal sternite (Figs. 1h, 2e) and on the trochanteral parts of the $4^{\text {th }}$ pair of walking legs (Figs 2c, g-i).
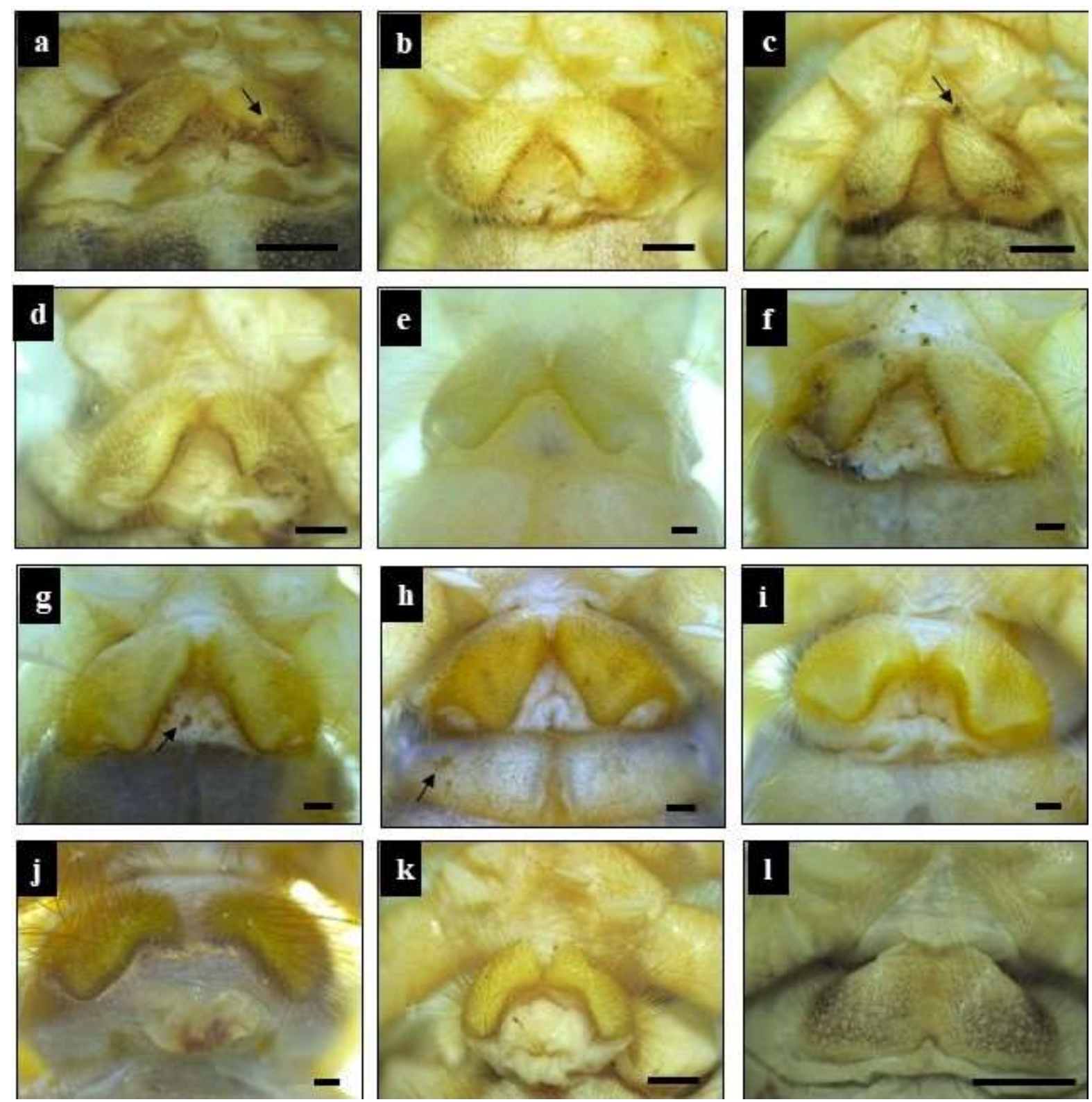

Figure 1. The genital organs of female gylippids: Gylippus (Gylippus) syriacus (a-d,j-l), Gylippus (Hemigylippus) bayrami (i), Gylippus (Paragylippus) monoceros (e-h). (Arrows show the cuticular damages) (Scale bars: 1mm) 

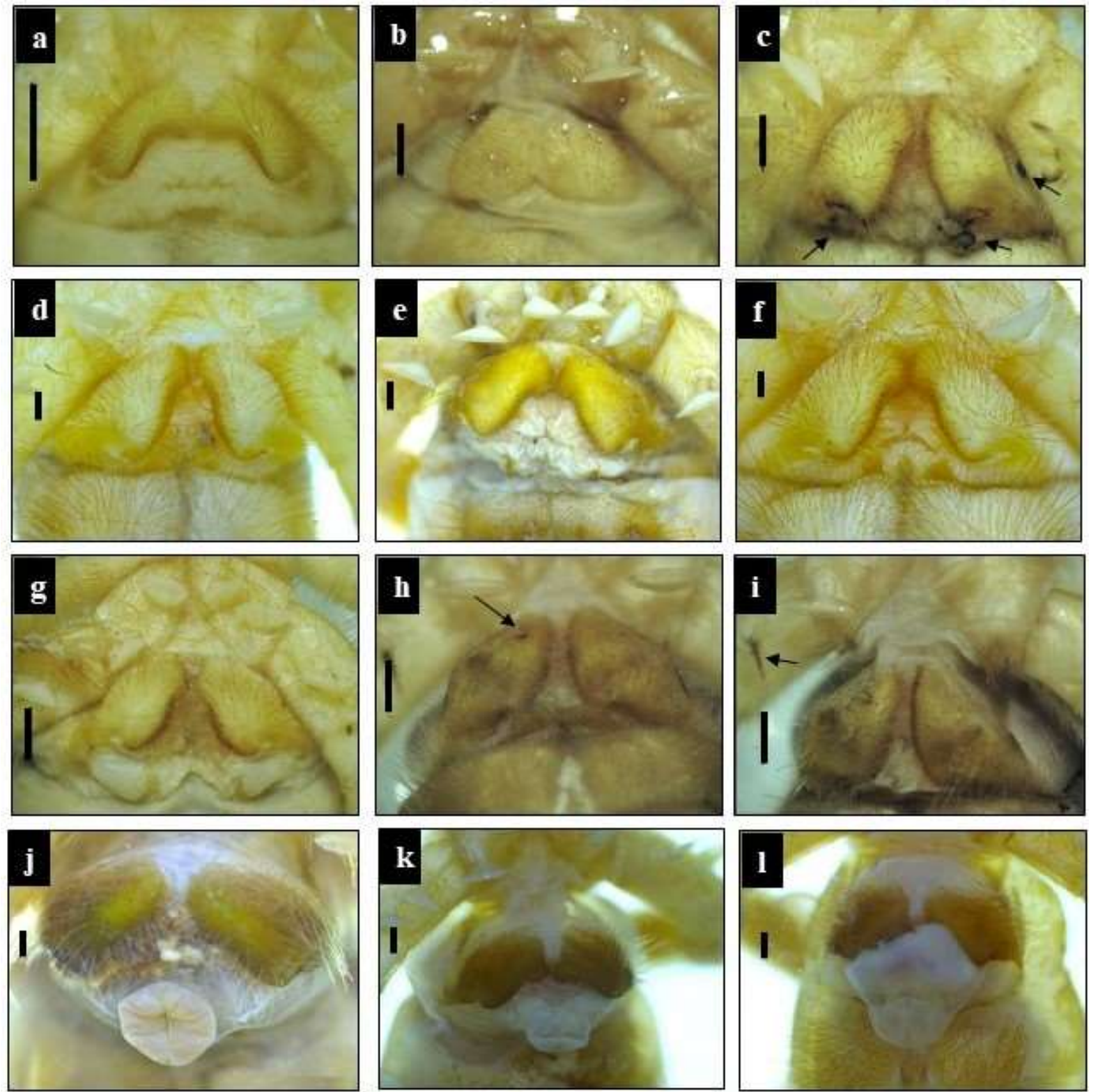

Figure 2. The genital organs of female gylippids: Gylippus (Gylippus) erseni (h-i), Gylippus (Gylippus) syriacus (a-g), Gylippus sp.(j-1) (Arrows show cuticular damages). (Scale bars: 1mm).

\section{Conclusions}

It is interpreted that female genital damages and mutilation during mating in some gylippids distributed in Turkey: Gylippus (Gylippus) erseni, Gylippus (Gylippus) syriacus, Gylippus (Hemigylippus) bayrami, Gylippus (Paragylippus) monoceros, Gylippus sp.

Hruskova-Martisova et al. emphasized that male solifuges could overcome female resistance by using luring behaviour and sexual coercion [6]. They described four behaviours during coercive mating: using strength or fast movement by males to grab a female, preventing females from counter-attack and escape, injuring the female during coercive copulation, and struggling to interrupt mating of females. Peretti and Willemart [12] indicated that the male Oltacola chacoensis clasps forcibly the female genital sternite with his chelicerae and holds the female $4^{\text {th }}$ pair of legs with his pedipalp. According to these behaviours, the cuticular damages observed in this study are caused by sexual coercion during premating and mating by the chelicerae and pedipalps of males. The male injures and mutilates females with the tip of his chelicerae and pedipalpal setal complex. It is observed that the male Gylippus (Paragylippus) monoceros cut off the left leg from the trochanter part of the female refused to mate in 
laboratory conditions (Author's personal observation). It is thought that the female could be copulated in nature and eggs could be fertilized; for this reason, female must be resisting another mating.

Uhl et al. [15] showed that the genital mutilations in different female spiders are caused by males plugging their embolar parts to epigynes of females. They claimed that these genital mutilations could occur with sexual cannibalism in some species associated with monogynous and terminal investment in a single mating partner.

Nessler et al. [11] also indicated that in Argiope bruennichi males, damaging their paired sexual organs during copulation, limiting the copulation as one copulation per pedipalp. According to Nessler et al., if genital damage increases in female, male fitness facilitates his escaping from aggressive female or by blocking the female fertilization ducts to prevent male mating attempts from other males. As a result, they suggested that this damage in this species increases the paternity success and reduces sperm competition with breaking off male pedipalps in the virgin female. In the present study, genital opening injuries (as in Fig.1j) must have occurred while inserting spermatophore by chelicerae into the female opening. But it is believed that males do this only for securing own generation; male does not substantially want to injure females just while inserting spermatophore he also inserts his chelicerae also into the female genital opening in this process male injure female willingly or not.

Muma [10] mentioned this as chewing motion during the contact phase of mating in eremobatids. The specimens having genital openings protruding outwards in Fig. $2 \mathrm{j}-1$ were collected by using pitfall traps. The specimens most probably fell into the traps shortly after mating, because the genital sternites seem opened as in contact phase. These swollen and degraded structures of female genital openings may also be caused by waiting for a long time in pitfall traps in antifreeze.

The changes in genital segment complicate the diagnose of solifuges, therefore females and males of a species must collect simultaneously for reliable diagnose.

\section{Acknowledgements}

I would like to express my sincere thanks to Dr. Ersen Aydın YAĞMUR and Dr. Halil KOÇ for helping me to get some specimens from different localities and joining my field works.

\section{Author's Contributions}

All contributions belong to the author in this paper.

\section{Statement of Conflicts of Interest}

No potential conflict of interest was reported by the author.

\section{Statement of Research and Publication Ethics}

The author declares that this study complies with Research and Publication Ethics.

\section{References}

[1] Birula, A.A. 1913. Monographie der Solifugen-Gattung Gylippus Simon. Annuaire du Musee Zoologique de l'Academie des Sciences de St.-Petersbourg, 18: 317-400, tabs. 7-11.

[2] Botero-Trujillo R., Ott R., Mattoni C.I., Nime M.F., Ojanguren-Affilastro A.A. 2019. Two new species of the sun-spider genus Gaucha from Argentina and Brazil (Solifugae, Mummuciidae). Zootaxa, 4551 (2): 180-194.

[3] Carvalho L S., Botero-Trujillo R. 2019. On the sun-spiders of the ibirapemussu species-group of the genus Gaucha Mello-Leitão, 1924 (Solifugae, Mummuciidae), with description of a new species. Zootaxa, 4700 (2): 289-298.

[4] Cushing P.E., Brookhart J.O. 2016. Nine new species of the Eremobates scaber species group of the North American camel spider genus Eremobates (Solifugae, Eremobatidae). Zootaxa, 4178 (4): 503-520. 
[5] Erdek M. 2019. Description of the new solifuge Gylippus (Paragylippus) hakkaricus sp. n. (Gylippidae, Solifugae). Zootaxa, 4695 (6): 559-567.

[6] Hrušková-Martišová M., Pekár S., Bilde T. 2010. Coercive copulation in two sexually cannibalistic camel-spider species (Arachnida: Solifugae). Journal of Zoology, 282 (2): 91-99.

[7] Klann A.E. 2009. Histology and ultrastructure of solifuges. Ernst-Moritz-Arndt-Universität, Greifswald. 1-228.

[8] Koç H., Erdek M. 2019. Gylippus (Gylippus) erseni sp. n. (Solifugae: Gylippidae: Gylippinae), a new solifuge species from Turkey. Acta Zoologica Bulgarica, 71 (2): 159-166.

[9] Maddahi H., Aliabadian M., Moradmand M., Mirshamsi O. 2019. New insights to the taxonomy of Rhagodes eylandti (Walter, 1889): A remarkable sexually dimorphic species (Solifugae: Rhagodidae). Zootaxa, 4648 (3): 494-510.

[10] Muma M.H. 1966. Mating behavior in the solpugid genus Eremobates Banks. Animal Behavior, 14: 346-350.

[11] Nessler S.H., Uhl G., Schneider J.M. 2007. Genital damage in the orb-web spider Argiope bruennichi (Araneae: Araneidae) increases paternity success. Behavioral Ecology, 18 (1): 174181.

[12] Peretti A.V., Willemart R.H. 2007. Sexual coercion does not exclude luring behavior in the climbing camel-spider Oltacola chacoensis (Arachnida, Solifugae, Ammotrechidae). Journal of Ethology, 25 (1): 29-39.

[13] Punzo F. 1998. The Biology of camel-spiders (Arachnida, Solifugae). Kluwer Academic Publishers, Boston, MA. 1-297.

[14] Roewer C.F. 1933. Solifugae, Palpigradi. In: Bronn, E.G., (Ed.), Klassen und Ordnungen des Tierreichs. 5. Arthropoda. IV. Arachnoidea und kleinere ihnen nahegestellte Arthropodengruppen. Vol. 5 (IV) (4) (2-3). Akademische Verlagsgesellschaft M.B.H., Leipzig, 161-480.

[15] Uhl G., Nessler S.H., Schneider J.M. 2010. Securing paternity in spiders? A review on occurrence and effects of mating plugs and male genital mutilation. Genetica, 138 (1): 75. 